\title{
Ways of building poetically in drawing and engraving of the artist Marcello Grassmann
}

\author{
Diego Alexandre de Souza (IC)
}

\begin{abstract}
This research aims to study the constructive ways in drawing and engraving of Marcello Grassmann (artist and printmaker born in Brazil São Simão-SP in 1925 and died in São Paulo-SP in 2013, whose artistic production exceeds six decades). I also propose a practical and artistic experience in drawing and engraving directed to the poetic ramifications of my graphic works built from the inventoried equipment through the research.
\end{abstract}

Key words: image, drawing, creation processes

\section{Introduction}

The study was divided into two stages. At first, I researched journals, books, and had contact with works of the artist in collections and libraries (Pinacoteca do Estado de São Paulo, Centro de Pesquisa em Gravura da Universidade Estadual de Campinas, Biblioteca Mário de Andrade, Instituto de Estudos Brasileiros da Universidade de São Paulo), the main focus of this first step was to investigate the poetic and language aspects of the artist in his graphic path. In the second stage, I went to the hometown of Grassmann - São Simão-SP - where is the Casa de Cultura Marcello Grassmann where I had access to the childhood environment and aesthetics initiation of the artist and access to works in drawing and engraving. I developed a series of drawings and engraving, experimenting and creating by our survey. As a way to organize the material and disseminate the study, I wrote an article in which I analyze a drawing, a woodcut and a engraving of Marcello Grassmann having as axis the sensitive nature of the visuality field and taking into account its relationship with the history of modern drawing, postmodern and contemporary Brazilian.

\section{Results and Discussion}

For this research we used the methodological strategy of grouping two blocks of research processes: inductive-reflective and heuristiccreative. In the first block efforts were concentrated on the study and contact with works of Grassmann through libraries and collections. In the second: experimentation and artistic creation in drawing and engraving, site definition for exhibition of the works created through the project, preparation of the article.
Image 1. Knight with shield

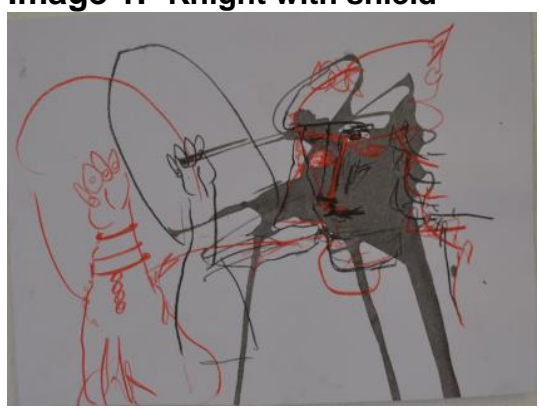

Conclusions

Through the survey it was found the importance of the artist Marcello Grassmann in the history of Brazilian art, particularly in the second half of the twentieth century and under the engraving, whose language Grassmann mastered and was also an "innovative" because it extended the technical overview inserting new technical methods for obtaining engraving works. In the research it was found heterotopic character Grassmann labor, graphic constructions that evoke propositions pertaining to displacements of time and space; images which comprise places, spaces and temporalities that are interrelated by several layers of meaning.

\section{Acknowledgement}

Lygia Arcuri Eluf

Willians César de Souza Torres Rocha Júlia de Souza

\footnotetext{
ABDALLA, A. C. Marcello Grassmann - sombras e sortilégio / gravuras e desenhos. Curitiba: Museu Oscar Niemeyer, 2010 BRUNNER, F. A Handbook of Graphic Reproduction Processes. New York: Hastings House Publishers, 1984

ELUF, L. A. (org.) Marcello Grassmann - Coleção Cadernos de Artista. Campinas-SP: Editora UNICAMP/Imprensa Oficial, 2010 HAYTER, S. W. New Ways of Gravure. A pratical guide. London: Routledge \& Kegan Paul Limited, 1949
} 